論文

\title{
水銀ディスペンサを用いたけい光ランプの特性
}

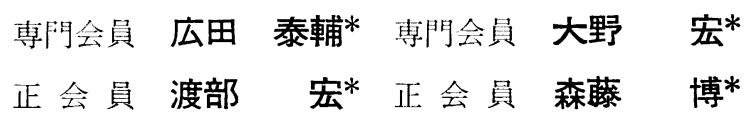

\section{Characteristics of Fluorescent Lamp Using Mercury Dispenser}

\author{
Taisuke Hirota (Fellow Member) Hiroshi Ono (Fellow Member) \\ Hiroshi Watanabe (Member) Hiroshi Morito (Member)
}

(Ome Works, Hitachi, Ltd.)

\begin{abstract}
Introduction of mercury in tubes is essential because fluorescent lamps exploit the ultraviolet radiation emitted by mercury atoms. The method of dropping liquid mercury into the tube has been employed to charge the tube with mercury. Such present method of production is advantageous in that it aids the exhaust in during processing but is disadvantageous in that it cansel various defects in lamp quality.

To eliminate such disadvantage, a manufacturing method which use a mercury dispenser such as an $\mathrm{Hg}$ alloy mounted around the electrodes, and releases mercury within the tube after sealing off by means of an induced current is introduced.

Advantages in use of mercury dispensar are as follows; (1) the quantity of mercury to be introduced into lamp is very precise, (2) the pressure fluctuation of Argon to be introduced can be reduced. Consequently it is possible to prevent the fluctuation of lamp life and increase its average life. In addition, improvement of lumen maintenance is achieved.
\end{abstract}

\section{1. ま え がき}

昭和 49 年の統計では, 光源類の総生産金額は約 1 千 億円で, このらち約 4 割がけい光ランプで占められてお り，けい光ランプは光源の主流製品となっている. 一般 に, けい光ランプには水銀とアルゴンガスが封入されて おり，水銀は紫外線放射によってけい光体を発光させ， またアルゴンは点灯特性を良好にするとともに，放電に よる電極の消耗をおさえる役目を果たしている.

さて, 水銀の封入方法は, けい光ランプが開発されて 以来, 液状の水銀粒を排気管を通じて滴下寸る方法がと

* 秘白製作所青梅工場

本原稿の一部は, 昭和 49 年照明学会東京支部大会および昭和 50 年 照明学会全国大会で発表したものでる.

Vol. 60 No. 2
られている. このよらな水銀封入法は, 発光要素となる 水銀を封入するといら本来の目的以外に，ランプの品質 に種々の影粒を与えている.

まず第 1 に，必要一定量の水銀を封入することが困難 であるということである.すなわち，水銀滴下後の蒸発 による損失, 水銀滴下器や排気管への付着分を補償する ため, 必要量の数倍を滴下しなければならず, 大部分の ランプには必要量以上の水銀が封入される。これは省資 源，省エネルギーの面から好ましくない.

第 2 に, 温度によって蒸気圧が大幅に変化する水銀を 排気中にランプ内に滴下することから， ランプの品質を 大きく左右する封入アルゴン圧が変動する主原因になっ ていることである.

以上のよらな欠点から, 現在の水銀封入方法は製品の 
品質向上に対する大きな障書の一つになっている.

一方，この欠点を解決する新しい製造法として，水銀 合金などの固形物を，あらかじめ電極付近に取り付けて おき，排努管溶封後に外部からの間接加熱で水銀を分 離, 放出させる方法が提案されている ${ }^{1)}$.この新しい水 銀封入法の採用には，間接的に他の製造プロセスの改善 が必要であること, 原価面でのマイナスがあるものの, 前記欠点の根本対策であることから，実用化を図るべく 主に特性面での検討を行なった.

以下，本報ではこのよらな新しい製造法によるけい光 ランプの品質向上を主体に述べることにする。

\section{2. 従来の製造法の問題点}

\section{1 ランプの品質に及ぼす要因}

従来のけい光ランプの製造要素が，品質に与える影響 を図 1 に示す．水銀粒を滴下してけい光ランプに水銀
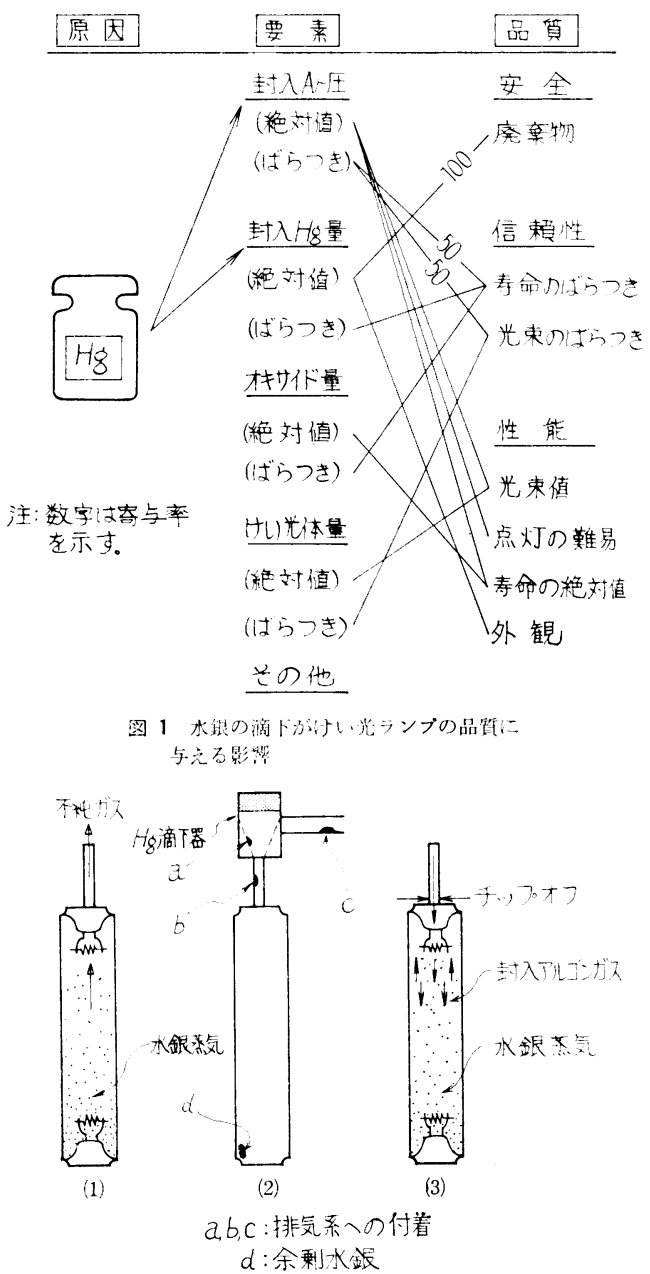

図 2 水銀滆下の作用

(1) 不純ガスの排気助成作用 (2) 封入水銀量への影㑼

（3）封入アルゴン压のばらつきへの影響
を封入する方法は，ランプの品質，すなわち安全性，信 頼性，性能の各方面にわたって影響を及ぼしていること がわかる，この一例をさらに具体的に示したのが図 2 である．水銀粒滴下には，(1)滴下された水銀の蒸気で管 内不純ガスの排気を助成する，(2)滴下器内あるいは排 気系への水銀付着による封入水銀量の变動, (3)水銀蒸気 による封入アルゴン压の変動といら三つの作用があり, このうち後 2 者が, 品質に悪影響を及ぼす要因となって いる.

\section{2 封入水銀 量}

ランプに封入された水銀は，点灯中にけい光体に吸着 されたり，放電によって生成される酸素と化合し，消耗 される2). したがって, 定格寿命を満足する必要水銀量 はけい光ランプの大きさ, 点灯中のランプ電流によって 異なる. 図 3 にグロースタート形ランプ $20 \mathrm{~W}$ と $40 \mathrm{~W}$ の場合の封入水銀量と, 継続点灯可能時間の関係を示し た。

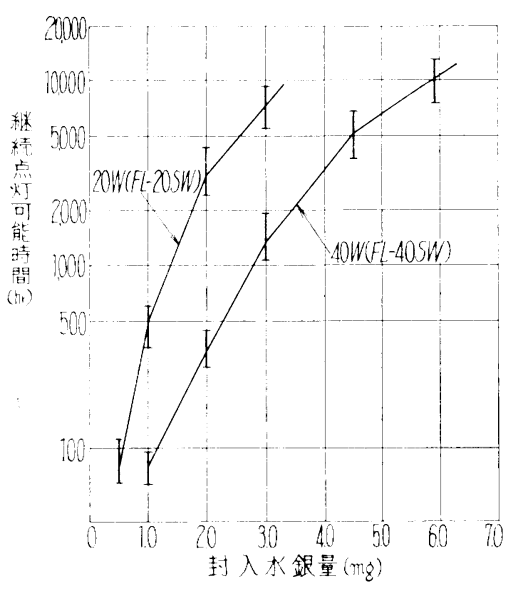

图 3 封入水銀量と秤続点灯能可時閂の関倸 （注）（1）陚料ランプ：水銀封入量のばらつき $10 \%$ ，アルゴン封入医 $2.7 \pm 0.1$ Torr, けい光体八口りん凌カルンウム，けい光 体付着量 FL-20 SW $4.0 \mathrm{mg} / \mathrm{cm}^{2}$ $\mathrm{FL}-40 \mathrm{SW} 5.1 \mathrm{mg} / \mathrm{cm}^{2}$

(2) 点灯条件：2時間45分点灯, 15分消灯 サイクル

(3) 陚料数: 各 $\mathrm{n}=5$ 本

封入水銀量のコントロールは, 水銀の封入量が最も精 度良くなる酸化第 2 水銀を使った水銀ディスペンサの保 有水銀量を変えて行なったものである. しかし実際にラ ンプ内に封入された水銀量を実測したわけではなく，水 銀ディスペンサの高周波加熱前後の重量差から，水銀放 出量を求めたものの同一ロットの水銀ディスペンサを用 い, 同一加熱条件で水銀を放出させた，同一ロットの 水銀量のばらつきは土10\%以内であった。おおよそ， $20 \mathrm{~W}$ では定格寿命 $7,500 \mathrm{hr}$ に対し約 $3.5 \mathrm{mg}, 40 \mathrm{~W}$ で は定格寿命 $10,000 \mathrm{hr}$ に対し約 $7.0 \mathrm{mg}$ の水銀が必要で 
ある．必要量以下の封入水銀量では，一定時間点灯後， 水銀蒸気圧の低下でランプの発光が停止し, ランプの寿 命が封入水銀量で左右されることになる.

一方, 現在の水銀滴下器による水銀の封入法では, 滴 下した水銀が滴下器内壁に補足されたり, 逆に滴下器内 壁に凝集している水銀を伴って滴下される場合があり， 実際にランプ内比入される水銀量は大きな変動をす る.このため, 必要封入量以下となることを防ぐために 滴下水銀量を多くする結果, 実際にランプ内に封入され る水銀量は，平均で必要量の約 3 倍となっている．この 必要以上の水銀はランプ管壁の最冷点部に凝集して, 外 観的に商品価値を低下させる原因となる。

\section{3 封入アルゴン压}

封入アルゴン氏は, 電極の保護のためには高いほらが 好ましいが，起動助成の面からは逆に低いほうがよく， 品種によって一定の最適值が存在する.このアルゴン压 は電極のオキサイド消耗，すなわちランプの寿命に大き

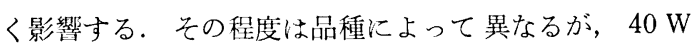
の場合の一例を図 4 亿示す ${ }^{3)}$. ランプの寿命は電極に 塗布されているオキサイド量汇もほぼ比例的に影響され るが, 実際の寿命変動は $\pm 4,000 \sim 5,000 \mathrm{~h}(\mathrm{FL}-40 \mathrm{~S})^{4}$ となっている. 図4 の結果から封入アルゴン圧による寿 命変動は, $1,000 \mathrm{~h} / 0.1$ Torr となるので寿命変動の約 50 \%が封入アルゴン圧の変動によるものといえる.

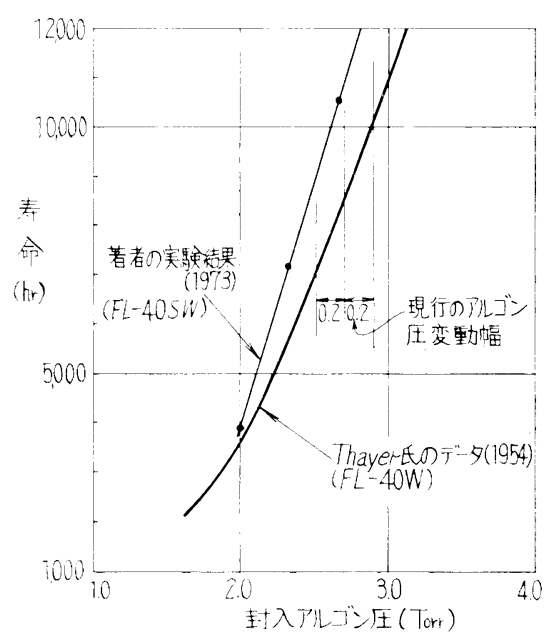

図 4 封入アルゴン堭とランプ寿命の関係 (注) (1) $3 \mathrm{~h}$ 点灯, $0.5 \mathrm{~h}$ 消灯 (2) $\mathrm{n}=5$

すなわちけい光ランプの寿命に関する信頼性は，封 入アルゴン圧の変動に大きく左右されているといえる.

また，封入アルゴン圧は明るさ，すなわち全光束にも 影響を与え，アルゴン压が高くなると全光束值は小さく なる、実際の製品では，封入アルゴン圧の変動汅る全 光束値の変動は約 $\pm 1.2 \%$ 程度となっている.

\section{3. 水銀ディスペンサ法の概要}

\section{1 水銀ディスペンサ材について}

水銀ディスペンサは, 高温度で水銀分離特性を有する 固形物とゲッタ材の組み合わせからなっておう，種々の タイプが考えられる。一例としてけい光ランプ用に開発 されたSAES 社製の GEMEDIS の仕様と特性を表 1 に 示与.

表 1 水銀ディスペンサ材の概要例

\begin{tabular}{|c|c|c|}
\hline & 項 目 & 内 \\
\hline 仕 様 & $\begin{array}{l}\text { 水鎚分離材 } \\
\text { ダッタ材 } \\
\text { 基 } r \text { 板 } \\
\text { 形 状 } \\
\text { 水銀含有量 }\end{array}$ & 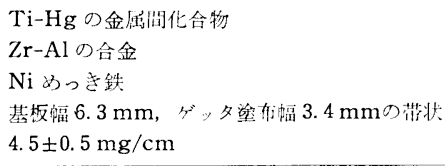 \\
\hline 特 性 & $\begin{array}{l}\text { 水銀放出量 } \\
\text { ガス放出量 }\end{array}$ & $\begin{array}{l}3.0 \pm 0.5 \mathrm{mg} / \mathrm{cm} \\
900^{\circ} \mathrm{C} \text { 加熱で最大 }\end{array}$ \\
\hline
\end{tabular}

一般に, けい光ランプ用水銀ディスペンサとしては次 の性能が要求される.

(1) 約 $500{ }^{\circ} \mathrm{C}$ 以下では水銀が分離しにくく，それ以 上の温度では叮及的に低い温度で分離すること。

（2）水銀分離のための加熱で放出される不純ガスを完 全汇再吸収するゲッタ材および構造であること.

（3）必要量の水銀を含有すること.

水銀を分離させるために，水銀ディスペンサを加熱す ると, 不純ガス（水素, 一酸化炭素, 二酸化炎素など） が放出される．この不純がスは加熱停止後, ディスペン サのゲッタ材によって大部分は再吸収されるが，管壁に 塗布されているけい光体が，一種のガス吸收材となって いるため，不純ガスの放出量が多いほど，管壁に吸着さ れるガス量も多くなり，動作時のランプ特性に覀影響を 与学る原因となる．したがって，不純がス放出がランプ 特性に悪影響を与えるかどうかは，放出ガス量の最大値 でほぼ決まってくる.

表 2 水銀ディスペンサの放出ガス量と点灯特性

\begin{tabular}{|c|c|c|c|c|}
\hline 故出ガス量 $($ Torr $\cdot \mathrm{cc} / \mathrm{mg})$ & & & & 1.7 \\
\hline エージング後起動䉓压 $(V)$ & & & & \\
\hline \multicolumn{5}{|c|}{ 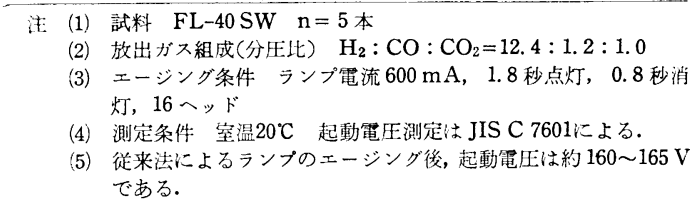 } \\
\hline
\end{tabular}

表 2 は, 水銀ディスペンサの放出ガス量と不純ガスの 影響を最も受けやすい点灯特性の関係を示したもので, 点灯特性を従来の量産品レベルに保つためには, 水銀放 出量 $1 \mathrm{mg}$ に対して約 3 Torr.cc 以下の不純ガス放出量 であることが好ましい，不純ガスのランプ特性への影響

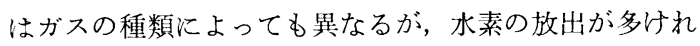




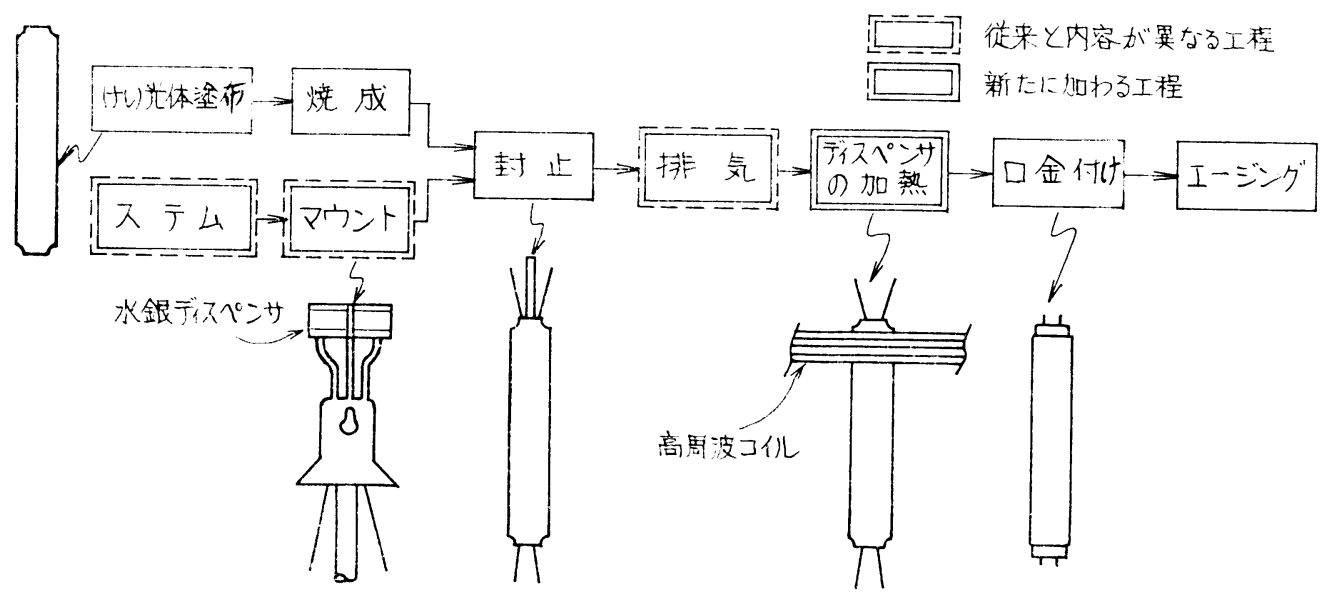

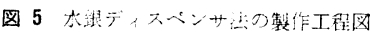

ば, 点灯特性, 全光東, 光束維持率まで瑟影響を与え る. 水銀ディスペンサを加熱し過ぎると（約 $1,000^{\circ} \mathrm{C}$ ) 再吸収能力が低下するので，水銀放出のための加熱は必 要以上に高温としないことが重要である.

\section{2 製造プロセスの開発}

水銀ディスペンサ法の製作工程概略を図 5 に示す. この方式の確立のためには, 次の二つのプロセス開発が 必要である。

(1) 水銀滴下による排気能力助成効果に代わる排気方 法の開発

（2）水銀ディスペンサの加熱方法の開発

上記(1)については，排気中に 10～20 Torr のアルゴン を管内に入れ，ランプ内の不純ガスと混合させた後，ポ ンプ能力の高い領域で排気する方法を採用した。表 3

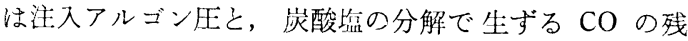
量，および点灯特性について示したものであるが，注入 アルゴン压を 10２0 Torr とすれば，水銀湳下に代わ门 得る特性となる.

表 3 ランプ内 $\mathrm{CO}$ 量と点灯特性

\begin{tabular}{|c|c|c|c|c|c|}
\hline 水 銀 滴 下 & 晾引 & & な & L & \\
\hline 注入アルゴン生(Torr) & 3.0 & 3.0 & 10.0 & 20.0 & 30.0 \\
\hline $\mathrm{CO}$ 量 (相対值) & 1.0 & 4.7 & 1.3 & 1.0 & 0.8 \\
\hline エージング前起和電压(V) & 169 & 203 & 176 & 170 & 167 \\
\hline
\end{tabular}

(2) CO 是测定 澌量分析計江上る.

武料：アルゴン封入なし，管壁温度 $20^{\circ} \mathrm{C}$

また，(2)については水銀の分離と同時に放出される水 素によるけい光体の発光効率の低下を防止する方法をと らなければならない、すなわち，高周波コイルによる高 周波電界によりランプ内で放電が発生すると, 水銀ディ スペンサから放出された水素が，ゲッタ材に再吸収され る前にけい光体に作用し5), あるいは起動補助用として 内面にネサ膜（酸化錫）を有するラピッドスタート形ラ
ンブではネサ膜を還元し，光束を低下させるという問題 がある.これに対しては，根本的な対策である高周波電 界の低下を行なった。すなわち，高周波出力回路汇電流 トランスを挿入し，また加熱コイルを 2 分割並列接続し た.これによってコイル間電圧を $20 \mathrm{~V}$ まで低下するこ とができ，高周波放電は完全に消隇した.

\section{4. 水銀ディスペンサ法によるランプ品質の 改善}

\section{1 封入水銀量精度の向上}

水銀ディスペンサ法では，ランプ内に封入される水銀 量はディスペンサに含有される水銀量と，ディスペンサ を加熱する温度と時間により決まるので，従来の水銀粒 滴下法より水銀量の封入精度は一段と向上する。图 6

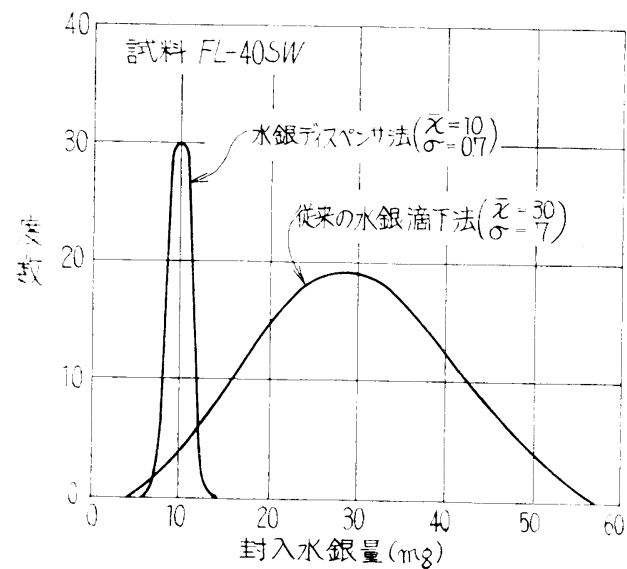

図 6 汁い光ランプ内封入我銀量の分布

(主) (1) 水銀量測定法

(1) 従来法：ランプ内の水銀を採集し，乙の拪 ジチゾンクロロホム抽出法で测定

(2) 水銀ディスペソサ法：水銀放出前後の重昌差 から求める. 誤差 (1) $10 \%$ 以内，(2) $5 \%$ 以内 
水銀ディスペンサを用いたけい光ランプの特性 専門会員 広田ほか

に封入量の分布を示す. 水銀ディスペンサ法による封入 量の変動は土 $20 \%$ となり，従来の約 $1 / 4$ となった. ラ ンプ1本あたりに封入される水銀量は, 品種によって異 なるが，従来の約 1/5～1/2 となる。 また，ランブ 1 本 あたりの製造で使用される水銀量は，従来の約 $1 / 10$ $1 / 4$ となり, 省資源, 省エネルギーの面から蚂去しくな る.

\section{2 信頼性の向上}

前述したように，けい光ランプの封入アルゴン死の変 動は，ランプ特性，寿命の信頼性に大きく影響学与兄 る. 水銀ディスペンサ法では, アルゴン封入時, 封入ア ルゴン生変動の主原因となる水銀蒸気が存在しないの で，封入アルゴン压の精度が向上する. 図 7 に封入ア

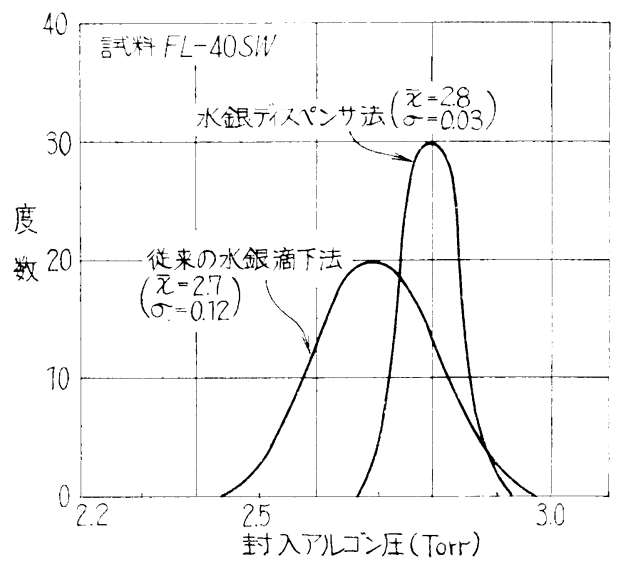

図 7 沙光ランプの封入アルゴン堅分倠

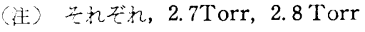
を狙った場合の分布を示す。

ルゴン圧の分布を従来法と比較して示す．水銀ディスペ ンサ法では，封入アルゴン圧の変動が \pm 0.1 Torr にな り, 従来の約 $40 \%$ とった。これによって光束の変動 は従来の約 $1 / 2$ となり，また寿命の変動も図8に示す ように従来の約 $1 / 2$ となり, ランプの信頼性が増した。

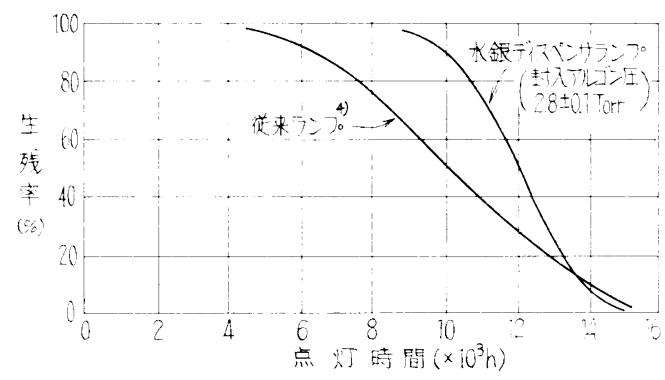

図 8 ケい光ランプの寿命特性

(注) (1) 試料ランプ FL-40 SW, (2) $3.0 \mathrm{~h}$ 点灯, $0.5 \mathrm{~h}$ 消灯, (3) 水銀ディスペン サ法の試料本数 75 本

\section{3 性能 $の$ 向上}

まず第 1 に，光束働程が改善されることがあげられ
る.これは, 過剩な水銀がランプ内に存在しないため に, 汁い光体面への水銀の凝集程度が小さくなること, 京よび電極付近に取り付けられた水銀ディスペンサのゲ ッタ作用により, 点灯中にランプ内の酸化性ガスが吸収 されるため, 酸化第 2 水銀などの壮い光体面への付着量 が減少することによる ${ }^{2)}$.

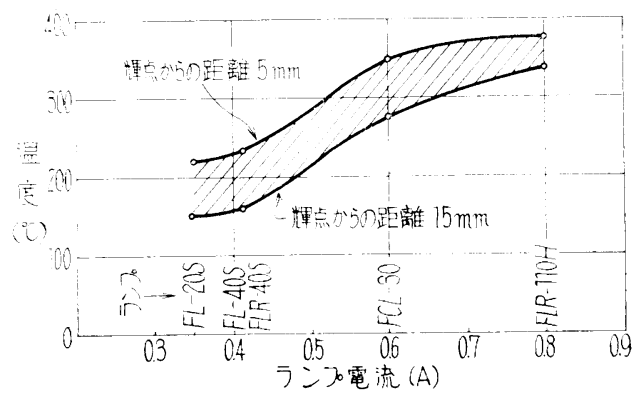

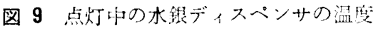

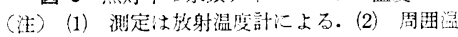
度 $20^{\circ} \mathrm{C}$, (3) 測定誤美 $\pm 10 \%$ 以内

点灯中の水銀ディスペンサの温度は, その取付け方法 によって異なるが，図 9に示すように，就よそラン プ電流の大きさと相関がある，特に高出力形と呼ばれる ランプ電流 $0.6 \mathrm{~A}$ 以上のランプでは, 水銀ディスペンサ の温度が $300{ }^{\circ} \mathrm{C}$ 以上となり，ゲッタ材の不純ガス吸収 能力が大きくなって, ゲッタ作用が十分発揮される領域 となる ${ }^{6)}$. 点灯時間に対する光束值の推移を図 10 に示 すが，水銀ディスペンサを用いた効果は，点灯時間が経 るにつれて顕著に現われている。

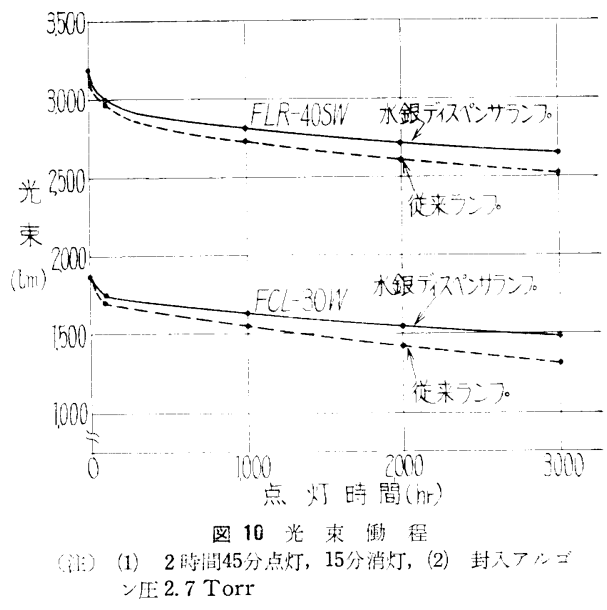

次に，光束維持率が向上したこと，就よび封入アルゴ ン圧の精度がよくなったことにより，ランプの平均寿命 の延長が容易となったことがあげられる.

けい光ランプの寿命を延ばすには，封入アルゴン圧を 一定にして電極に塗布するオキサイド量を多くする， あ

Vol. 60 No. 2 
るいは封入アルゴン圧を高くして, オキサイドの消耗速 度を扰さえるの二つの方法がある.しかし，けい光ラン プは継続点灯が可能であっても, 光束が初期 (100 hr) の $70 \%$ に低下すると経済的に寿命とみなされるため ${ }^{7}$, 単に前記のような方法により，寿命を延長することには 難点があったが，水銀ディスペンサ法による光束維持率 の向上により，実質的な寿命の延長が達成される，延長 できる寿命の長さは品種によって異なるが，括およそ従 来の $1.2 \sim 1.4$ 倍の長寿命化が可能である. これによっ て,けい光ランプ1本あたりの寿命までの総光量も, 従 来の $1.2 \sim 1.4$ 倍となり，実質的な効率の向上となる.

また，ランプ内に過剩な水銀が封入された場合には， ランプ完成後，あるいは点灯中に管壁の最冷点に水銀が 凝集して外観的にも好ましくなく, また光束が低下する 原因となる、特に，起動補助用として管内面にネサ（酸 化錫）膜を施したラピッドスタート形ランプでは，水銀 のけい光体面への凝集が, 放電によってネサ膜の破壊に 発展し, 著しく外観をそこなう。これらの外観不良を図 11 に示す. しかし, この外観不良の発生は図 12 に示す ように水銀の封入量と相関があり, 封入量を少なくする ことによってその発生を抑制することができるので, 水 銀ディスペンサの使用が効果的である.

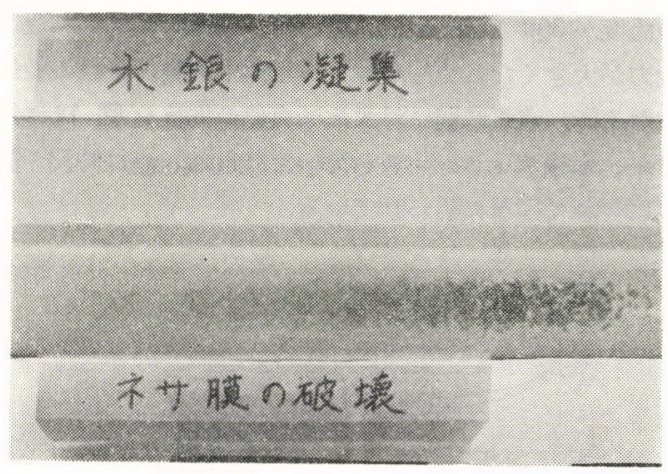

図 11 水銀凝集により発生した外锶不良 (ラピッドスタート形内面ネサランブ)

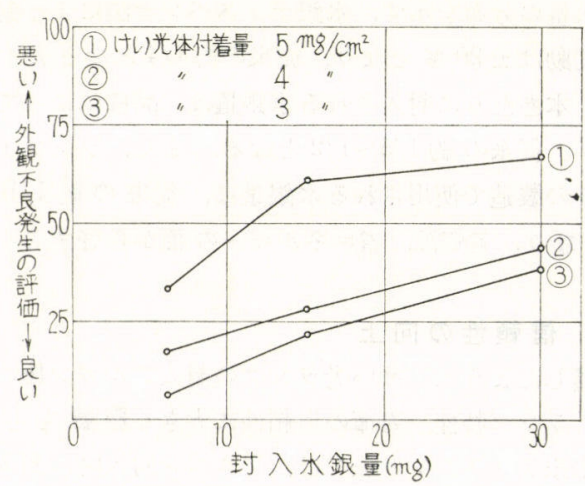

図 12 封入水銀量と水銀凝集による外観不良発生の関係

(注) (1) 試料 FLR-40 SW, (2) 周用温度 $10 \sim 20{ }^{\circ} \mathrm{C}$, （3）点灯 =実使用状態，（4）総点灯時間 $1,000 \mathrm{hr}$

\section{5. 結言}

省資源, 省エネルギーの面から従来の光源を見直し, これらの点に適応した新しい光源や製造方法の開発が, 現在要求される技術革新の一つとなってきている. 水銀 ディスペンサを用いた新しいけい光ランプの製造法で は, 封入水銀量の精度向上, 封入アルゴン圧の精度向上 によるランプ特性と寿命の信頼性向上, および総光量増 加による性能の向上が達成される, これは, 現在求めら れている技術革新の一つであるといえる.

\section{参考 文 献}

(1) 米国特許 : $3,385,644$ (1966)

(2) 真 室：照学誌 42 (昭 33)

(3) R. N. Thayer: Illum. Engng 49 (1954) 527

(4) 照明学会：照明のデータブック (1968) 114

(5) Richard W. Mooney, W. Galvin Gungle: Illum Engng 12 (1956) 793

(6) T. A. Giorgi, P. della Porta: Residual Gases in Electron Tubes (1972) 123

（7）日本規格協会：日本工業規格 C 7601 (1967)

（受付 1975 年 5 月 23 日） 